\title{
'Glutamine(amide): 2-Oxoglutarate Amino Transferase Oxido-reductase (NADP)', an Enzyme Involved in the Synthesis of Glutamate by Some Bacteria
}

\author{
By J. L. MEERS* AND D. W. TEMPEST \\ Microbiological Research Establishment, Porton, Near Salisbury, Wiltshire \\ AND C. M. BROWN \\ Department of Microbiology, Medical School, University of Newcastle upon Tyne
}

(Accepted for publication 8 October 1970)

\begin{abstract}
SUMMARY
Ammonia-limited Aerobacter aerogenes, Erwinia carotovora, Pseudomonas fluorescens, Bacillus subtilis and B. megaterium synthesized glutamate from $\mathrm{NH}_{3}$ and 2-oxoglutarate by a process that involved first the synthesis of glutamine and then the reductive transfer of the glutamine amide-nitrogen to the 2-position of 2-oxoglutarate. The latter step required the recently reported enzyme 'glutamine(amide): 2-oxoglutarate amino-transferase oxido-reductase (NADP)', some further properties of which are described here. This enzyme, from different organisms, always had a well-defined maximum activity at a pH value between 7.5 and 8.0 ; it had an apparent $K_{m}$ for 2-oxoglutarate between $0 . \mathrm{I}$ and $2.0 \mathrm{mM}$ and an apparent $K_{m}$ for glutamine between 0.2 and I. $8 \mathrm{mM}$. Glutamate (the metabolic end-product) and $\mathrm{Mg}^{2+}$ strongly inhibited the enzyme from Gram-negative bacteria but less so that from Grampositive species. Synthesis of glutamate by this enzyme required NADPH, and NADH was inactive; pyruvate, oxaloacetate, 2-oxobutyrate and 2oxoisovalerate could not substitute for 2-oxoglutarate, nor could the requirement for glutamine be met by asparagine, citrulline, arginine or urea. Although conditions that favoured the synthesis of this enzyme generally also favoured synthesis of glutamine synthetase and caused suppression of glutamate dehydrogenase formation, a close correlation between the bacterial contents of these different enzymes was not apparent.
\end{abstract}

\section{INTRODUCTION}

In order to grow in a simple salts medium in which $\mathrm{NH}_{3}$ provides the sole source of utilizable nitrogen, micro-organisms must possess some mechanism for the synthesis of amino acids from $\mathrm{NH}_{3}$ and intermediary metabolites. In many bacteria this requirement can be met solely by glutamate dehydrogenase (EC I.4. I .4), which reductively aminates 2-oxoglutarate to glutamate. This enzyme was found to be present in substantial amounts in glucose-limited Aerobacter aerogenes but, surprisingly, was almost absent from these organisms when they were grown in media that lacked sufficient $\mathrm{NH}_{3}$ to allow growth to occur at its maximum rate. Examination of these $\mathrm{NH}_{3}$ limited organisms showed that they synthesized glutamate by a two-step process that involved first the amidation of endogenous glutamate to glutamine and then the

* Present address: Novo Industri A/S., Fuglebakkevej I 15, 2200 Copenhagen N, Denmark. 
reductive transfer of the glutamine amide-nitrogen to the 2-position of 2-oxoglutarate (thereby producing a net synthesis of glutamate) (Meers, Tempest \& Brown, I970; Tempest, Meers \& Brown, I970 a). The latter step involved a novel enzyme, 'Glutamine (amide) : 2-oxoglutarate amino-transferase oxido-reductase (NADP)' (for convenience designated GOGAT), and the present communication provides a more detailed description of its properties. We also report on the distribution of this enzyme in other bacteria and on the differing relationships found between this and the metabolically associated enzymes, glutamine synthetase and glutamate dehydrogenase, in different bacteria.

\section{METHODS}

Organisms. Aerobacter aerogenes (NCTC 4I8), Erwinia carotovora (MRE 604), Pseudomonas fluorescens (KB-I), Bacillus subtilis var. niger (ATCC 9372), B. subtilis W 23 and $B$. megaterium $\mathrm{KM}$ were maintained on tryptic meat digest agar slopes by monthly subculture at $35^{\circ}$.

Cultural conditions. Organisms were grown in $500 \mathrm{ml}$. chemostats (Herbert, Phipps \& Tempest, 1965) in simple salts media that contained growth-limiting concentrations of either glucose or $\mathrm{NH}_{3}$ (see Evans, Herbert \& Tempest, 1970). The dilution rate was maintained at $0.3 \mathrm{~h} . .^{-1}, \mathrm{pH} 6.8$ and temperature $35^{\circ}$. Culture effluent was collected in an ice-cooled receiver and the organisms subsequently harvested by centrifugation.

Extraction of enzymes. Extracts were prepared by disrupting thick suspensions of organisms (containing about $50 \mathrm{mg}$. equivalent dry wt organisms $/ \mathrm{ml}$, in $50 \mathrm{~mm}$-tris buffer, $\mathrm{pH} 7 \cdot 6$, plus Io mM mercaptoethanol) in a Hughes press (Hughes, 195I). The crushed and thawed paste was diluted with about 3 volumes of the above tris buffer and centrifuged $\left(30 \mathrm{~min}\right.$. at $\left.10,000 \mathrm{~g}, 4^{\circ}\right)$ to sediment the unbroken cells and debris. The clear supernatant fluid, which contained between 5 and $10 \mathrm{mg}$. protein $/ \mathrm{ml}$., contained the required enzymes.

Assaying of enzymes. The activities of glutamate dehydrogenase and GOGAT were measured spectrophotometrically by recording the rate of oxidation of NADPH (indicated by a change in $E_{340 \mathrm{~nm}}$ ) following addition of the extract (0.05 to $0.3 \mathrm{ml}$.) to a solution containing 2-oxoglutarate ( $5 \mathrm{mM}), \mathrm{NADPH}(0.25 \mathrm{mM})$ and either $\mathrm{NH}_{4} \mathrm{Cl}$ $(40 \mathrm{~mm})$ or glutamine $(5 \mathrm{~mm})$ in $3.0 \mathrm{ml}$. final volume of tris buffer $(50 \mathrm{~mm})$, pH $7 \cdot 6$. Measurements were made with a Spectronic-20 spectrophotometer (Bausch \& Lomb Inc., New York, U.S.A.) using tubes of $\mathrm{I} \cdot \mathrm{I} \mathrm{cm}$. internal diameter. The results, corrected for a small endogenous NADPH oxidase activity, are expressed as nmoles NADPH oxidized $\left(37^{\circ}, \mathrm{pH} 7^{\cdot 6}\right) / \mathrm{min}$./mg. protein. $\mathrm{pH} /$ activity curves were determined by adding graded amounts of either $\mathrm{NaOH}$ or $\mathrm{HCl}$ to the above test solutions and measuring the $\mathrm{pH}$ immediately following the assay of the enzyme activity. $K_{m}$ values for ammonia, glutamine and 2-oxoglutarate were determined by conventional methods (Dixon \& Webb, 1964).

Analytical procedures. In some experiments glutamic acid formation was determined directly by precipitating the protein from the reaction mixture with $0.25 \mathrm{~N}-\mathrm{HClO}_{4}$ ( 5 min., $4^{\circ}$ ) and applying the clear extract to the columns of a Technicon automatic amino acid analyser. Concentrations of glutamate were assessed by measurement of peak areas, on the recorder charts, and reference to standard curves prepared with pure solutions of glutamic acid in $0.25 \mathrm{~N}-\mathrm{HClO}_{4}$. Protein was estimated by the biuret method of Stickland (I95I). 


\section{RESULTS}

\section{Assay and properties of GOGAT from Aerobacter aerogenes}

Initially GOGAT in extracts of $\mathrm{NH}_{3}$-limited Aerobacter aerogenes was detected by the formation of glutamic acid when mixtures containing the enzyme plus glutamine $(5 \mathrm{mM})$ and 2-oxoglutarate $(5 \mathrm{mM})$ were incubated at $37^{\circ}$, and $\mathrm{pH} 7 \cdot 6$, with and without the addition of $0.25 \mathrm{~mm}$ NADPH. Some formation of glutamate from glutamine occurred in the absence of NADPH due, presumably, to the action of a glutaminase (EC 3.5.I.2), but considerably more glutamate was formed, without concomitant production of $\mathrm{NH}_{3}$, when NADPH was present. Extracts of glucose-limited A. aerogenes possessed a small glutaminase activity but would not catalyse a reaction producing a net synthesis of glutamate from glutamine and 2-oxoglutarate. However, these extracts, unlike those from $\mathrm{NH}_{3}$-limited $A$.aerogenes, readily and rapidly formed glutamate when incubated with 2-oxoglutarate $(5 \mathrm{~mm}), \mathrm{NH}_{4} \mathrm{Cl}(2 \mathrm{OmM})$ and NADPH $(0.25 \mathrm{~mm})$. Clearly, glucose-limited organisms possessed an active glutamate dehydrogenase whereas $\mathrm{NH}_{3}$-limited organisms possessed the alternative glutamatesynthesizing enzyme-GOGAT. Since the $\mathrm{NH}_{3}$-limited bacterial extracts lacked

\section{Table 1. The distribution of GOGAT and glutamate dehydrogenase in bacteria grown in different media}

The organisms were grown in chemostat cultures in media that contained growth-limiting concentrations of the nutrients specified. The dilution rate was $0.3 \mathrm{~h}^{-1}\left(35^{\circ}, \mathrm{pH} 6.8\right)$ and the organisms were collected and extracted as described in Methods. The activities quoted are the values determined under optimum conditions, and are expressed as nmoles NADPH oxidized $/ \mathrm{min} . / \mathrm{mg}$. protein. Pool glutamate levels were determined by extracting organisms with $0.25 \mathrm{~N}-\mathrm{HClO}_{4}\left(4^{\circ}\right.$, Io min.), separating the amino acids and assaying them automatically with a Technicon automatic amino acid analyser.

\begin{tabular}{|c|c|c|c|c|}
\hline \multirow[b]{2}{*}{ Organism } & \multirow[b]{2}{*}{ Growth condition } & \multirow[b]{2}{*}{$\begin{array}{c}\text { Pool } \\
\text { glutamate } \\
\text { level }(\mathrm{mM})\end{array}$} & \multicolumn{2}{|c|}{ Specific activities } \\
\hline & & & GOGAT & $\begin{array}{c}\text { Glutamate } \\
\text { dehydro- } \\
\text { genase }\end{array}$ \\
\hline Aerobacter aerogenes & $\begin{array}{l}\text { Glucose-limited } \\
\mathrm{NH}_{3} \text {-limited } \\
\mathrm{NH}_{3} \text {-limited }+2 \% \mathrm{NaCl} \\
\text { *N(glutamate)-limited } \\
\text { Phosphate-limited } \\
\text { *P-limited + glutamate }\end{array}$ & $\begin{array}{r}3 \cdot 4 \\
5 \cdot 8 \\
30 \cdot 2 \\
5 \cdot 0 \\
1 \cdot 1 \\
>20\end{array}$ & $\begin{array}{r}<\mathrm{I} \\
66 \\
32 \\
<\mathrm{I} \\
<\mathrm{I} \\
<\mathrm{I}\end{array}$ & $\begin{array}{r}560 \\
19 \\
36 \\
<1 \\
600 \\
10\end{array}$ \\
\hline Erwinia carotovora & $\begin{array}{l}\text { Glucose-limited } \\
\mathrm{NH}_{3} \text {-limited } \\
\text { *N(glutamate)-limited } \\
\text { Phosphate-limited } \\
\text { *P-limited + glutamate }\end{array}$ & $\begin{array}{r}5 \cdot 5 \\
4 \cdot 7 \\
4 \cdot 6 \\
3 \cdot 0 \\
>30\end{array}$ & $\begin{array}{r}50 \\
26 \\
<1 \\
25 \\
<1\end{array}$ & $\begin{array}{l}<\text { I } \\
<\text { I } \\
<\text { I } \\
<1 \\
<\text { I }\end{array}$ \\
\hline seudomonas fluorescens & $\begin{array}{l}\text { Glucose-limited } \\
\mathrm{NH}_{3} \text {-limited }\end{array}$ & $\begin{array}{l}4.0 \\
9.6\end{array}$ & $\begin{array}{l}77 \\
64\end{array}$ & $\begin{array}{r}480 \\
10\end{array}$ \\
\hline $\begin{array}{l}\text { Bacillus subtilis } \\
\text { var. niger }\end{array}$ & $\begin{array}{l}\text { Glucose-limited } \\
\mathrm{NH}_{3} \text {-limited }\end{array}$ & $\begin{array}{l}130 \\
103\end{array}$ & $\begin{array}{l}<\mathrm{I} \\
\mathrm{I} 40\end{array}$ & $\begin{array}{r}800 \\
30\end{array}$ \\
\hline megaterium & $\begin{array}{l}\text { Glucose-limited } \\
\mathrm{NH}_{3} \text {-limited }\end{array}$ & $\begin{array}{l}57 \\
62\end{array}$ & $\begin{array}{l}750 \\
140\end{array}$ & $\begin{array}{l}\text { I0 } \\
\text { I0 }\end{array}$ \\
\hline subtilis $\mathrm{W} 23$ & $\begin{array}{l}\mathrm{Mg}^{2+} \text {-limited } \\
\mathrm{NH}_{3} \text {-limited }\end{array}$ & $\begin{array}{l}142 \\
125\end{array}$ & $\begin{array}{l}78 \\
43\end{array}$ & $\begin{array}{l}2 \\
5\end{array}$ \\
\hline
\end{tabular}

* Glutamate was the sole source of utilizable nitrogen in these cultures. 
glutamate dehydrogenase activity, the possible formation of glutamate from glutamine, 2-oxoglutarate and NADPH via a two-step process involving deamidation of glutamine (with glutaminase) followed by amination of 2-oxoglutarate (with glutamate dehydrogenase) could be discounted. The only possible interpretation of the above results is that $\mathrm{NH}_{3}$-limited $A$. aerogenes contained an enzyme (GOGAT) that catalysed the direct transfer of the glutamine amide-nitrogen to the 2-position of 2-oxoglutarate. Thus, although this enzyme, in conjunction with glutamine synthetase, synthesized glutamate from $\mathrm{NH}_{3}$ and 2-oxoglutarate, it did so by a pathway that did not involve glutamate dehydrogenase (Tempest et al. 1970a); the enzymes involved in this pathway were seemingly only synthesized by $A$. aerogenes under conditions where glutamate dehydrogenase was either not present or not functioning (Table I).

(a)

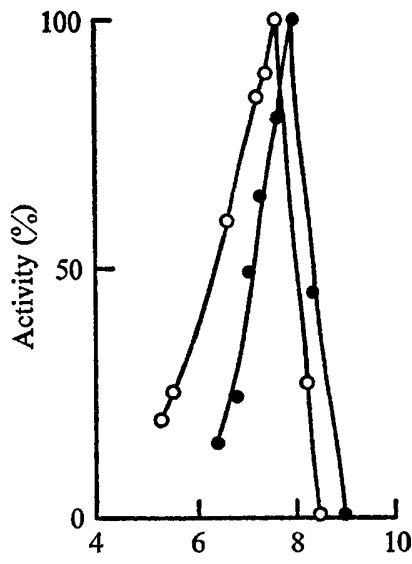

(b)

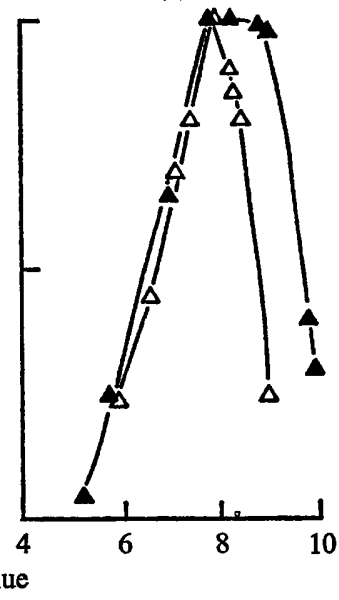

Fig. 1. Influence of $\mathrm{pH}$ on the activity of GOGAT extracted from (a) Gram-negative bacteria -Aerobacter aerogenes $(O)$ and Erwinia carotovora $(\bullet)$-and $(b)$ Gram-positive bacteriaBacillus subtilis var. niger $(\triangle)$ and $B$. subtilis $\mathrm{w}_{23}(\mathbf{\Delta})$-grown in $\mathrm{NH}_{3}$-limited chemostat cultures (dilution rate $=0.3 \mathrm{~h}^{-1}, 35^{\circ}, \mathrm{pH} 6.8$ ).

To assay GOGAT activity, use was made of the fact that oxidation of NADPH to NADP accompanied the transfer of the glutamine amide-nitrogen to 2-oxoglutarate. This oxidation of NADPH could be followed spectrophotometrically at $340 \mathrm{~nm}$.

Influence of $p H$ on GOGAT activity. This was studied by using the spectrophotometric assay described above. The enzyme from $\mathrm{NH}_{3}$-limited Aerobacter aerogenes had a sharp optimum activity at $\mathrm{pH} 7.6$; at a $\mathrm{pH}$ value of 6.8 the activity was less than $70 \%$ of the maximum value, and at $\mathrm{pH} 8.4$ it was almost nil (Fig. I $a$ ). Similar sharp $\mathrm{pH} /$ activity profiles were observed with the GOGAT enzymes extracted from $\mathrm{NH}_{3}$ limited cultures of Erwinia carotovora and Bacillus subtilis var. niger (Fig. $1 a, b$ ). The enzyme from $B$. subtilis $\mathbf{w} 23$ was different in that its activity was much less affected by high $\mathrm{pH}$ values; it showed near-maximal activity over a range of $\mathrm{pH}$ from $7 \cdot 7$ to 9.0 (Fig. $\mathrm{x} b$ ).

Influence of glutamine and 2-oxoglutarate concentrations on GOGAT activity. Again, this was studied using the rate of oxidation of NADPH as a measure of GOGAT activity (endogenous NADPH oxidase activity being subtracted). Varying the concentration of either glutamine or 2-oxoglutarate in the incubation mixture (see 
Methods) caused the GOGAT activity to change in a manner characteristic of a Michaelis-Menten-type function. With the enzyme from $\mathrm{NH}_{3}$-limited Aerobacter aerogenes, the concentrations of glutamine and 2-oxoglutarate supporting halfmaximal GOGAT activity were $\mathrm{I} \cdot 8$ and $2.0 \mathrm{~mm}$ respectively (Table 2 ). The $K_{m}$ values for glutamine and 2-oxoglutarate of enzymes extracted from several different Grampositive and Gram-negative bacteria are also shown in Table 2; invariably they were less than the corresponding $K_{m}$ values for the $A$. aerogenes enzyme.

Table 2. Apparent Michaelis constants for glutamine and 2-oxoglutarate of GOGAT extracted from several different Gram-positive and Gram-negative bacteria

\begin{abstract}
The organisms were grown in $\mathrm{NH}_{3}$-limited chemostat cultures at a dilution rate of $0.3 \mathrm{~h}^{-1}$ $\left(35^{\circ}, \mathrm{pH} 6.8\right)$. Bacterial extracts, prepared as described in Methods, were incubated at $37^{\circ}$ and $\mathrm{pH} 7.6$ with varying concentrations of substrate, and the rates of NADPH oxidation were measured spectrophotometrically. The values given below are those concentrations of each substrate supporting half-maximal GOGAT activity, all other reactants being provided in concentrations assumed to be in excess of requirement.
\end{abstract}

\begin{tabular}{|c|c|c|}
\hline \multirow[b]{2}{*}{ Organism } & \multicolumn{2}{|c|}{$\begin{array}{l}\text { Apparent } K_{m} \text { values of } \\
\text { GOGAT for }\end{array}$} \\
\hline & $\underset{(\mathrm{mM})}{\text { Glutamine }}$ & $\begin{array}{c}\text { 2-Oxoglutarate } \\
\text { (mM) }\end{array}$ \\
\hline Aerobacter aerogenes & $\mathrm{I} \cdot 8$ & $2 \cdot 0$ \\
\hline Pseudomonas fluorescens & 0.4 & 0.1 \\
\hline Erwinia carotovora & $\mathrm{I} \cdot 6$ & $0 . \mathrm{I}$ \\
\hline Bacillus subtilis var. niger & $\mathrm{I} \cdot 7$ & $0 . \mathrm{I}$ \\
\hline B. subtilis W 23 & 0.2 & 0.04 \\
\hline B. megaterium & 0.3 & 0.04 \\
\hline
\end{tabular}

Substrate specificity of GOGAT. The enzyme from Aerobacter aerogenes displayed maximal activity in an assay mixture containing glutamine $(5 \mathrm{mM})$, 2-oxoglutarate $(5 \mathrm{~mm})$ and NADPH $(0.25 \mathrm{~mm})$ in $50 \mathrm{~mm}$ tris, $\mathrm{pH} 7.6$. Substituting NADH $(0.25 \mathrm{~mm})$ for NADPH decreased the activity almost to zero. Similarly, pyruvate, oxaloacetate, 2-oxobutyrate or 2-oxoisovalerate (each at $5 \mathrm{mM}$ ) would not substitute for 2-oxoglutarate, nor would asparagine, citrulline, arginine or urea (each at $5 \mathrm{~mm}$ ) substitute for glutamine. The requirements for NADPH, glutamine and 2-oxoglutarate were seemingly absolute.

Inhibitors. The activity of GOGAT was not appreciably affected when $25 \mathrm{mM}-\mathrm{Na} / \mathrm{K}$ phosphate buffer $\left(\mathrm{pH}^{\circ} \cdot 6\right)$ replaced the tris buffer. However, higher concentrations of $\mathrm{Na}^{+}$and, to a lesser extent, $\mathrm{K}^{+}$did lower the activity of the enzyme and $\mathrm{Mg}^{2+}$ was markedly inhibitory (Fig. 2).

\title{
Regulation of GOGAT synthesis and activity
}

With $\mathrm{NH}_{3}$-limited and glucose-limited cultures of Aerobacter aerogenes, a reciprocal relationship seemingly existed between the cellular contents of GOGAT and glutamate dehydrogenase. Thus conditions that favoured the synthesis of GOGAT caused suppression of glutamate dehydrogenase synthesis, and vice versa. In fact, with all the bacteria examined, $\mathrm{NH}_{3}$-limitation invariably caused repression of glutamate dehydrogenase synthesis (in those organisms which otherwise produced this enzyme) but permitted GOGAT synthesis (Table I). Some organisms (particularly Erwinia carotovora, but also, possibly, Bacillus megaterium and B. subtilis $\mathrm{w} 23$ ) seemingly lacked 
a glutamate dehydrogenase but could still grow readily in simple salts media in which $\mathrm{NH}_{3}$ provided the sole source of utilizable nitrogen; in these cases GOGAT was constitutively synthesized. As with glutamate dehydrogenase, however, synthesis of GOGAT was totally repressed when L-glutamate $(50 \mathrm{mM})$ was added to the growth medium (Table I). Inexplicably, using L-glutamate as the $\mathrm{N}$-limiting component of

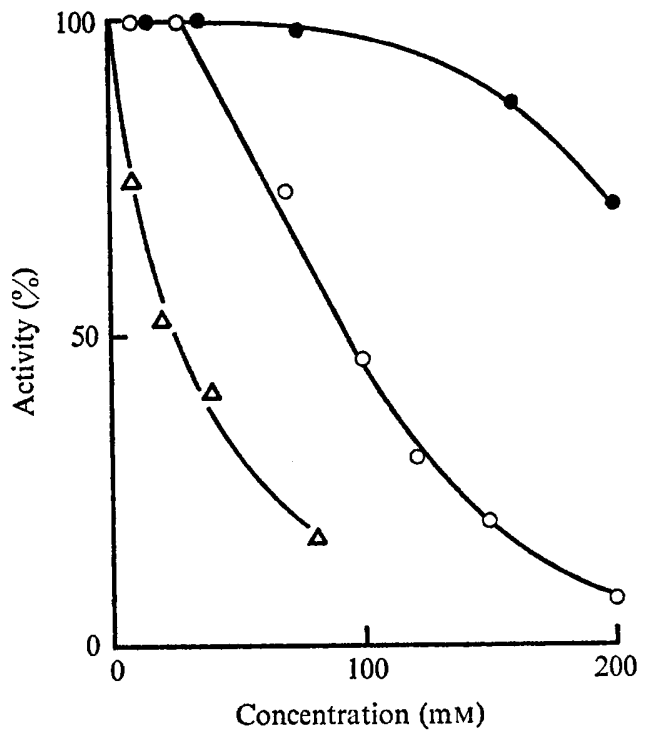

Fig. 2. Influence of various concentrations of $\mathrm{Na}^{+}(O), \mathrm{K}^{+}(\bullet)$ and $\mathrm{Mg}^{2+}(\triangle)$ on the activity of GOGAT extracted from $\mathrm{NH}_{3}$-limited Aerobacter aerogenes organisms.

(a)

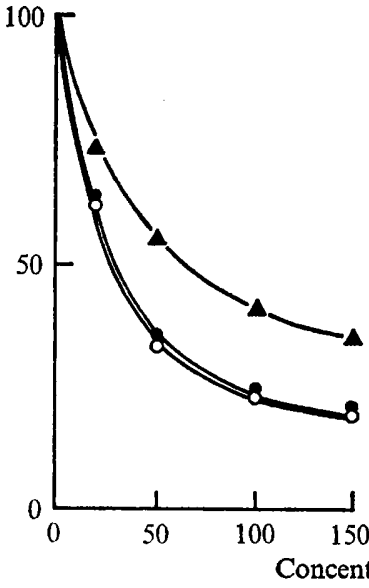

(b)

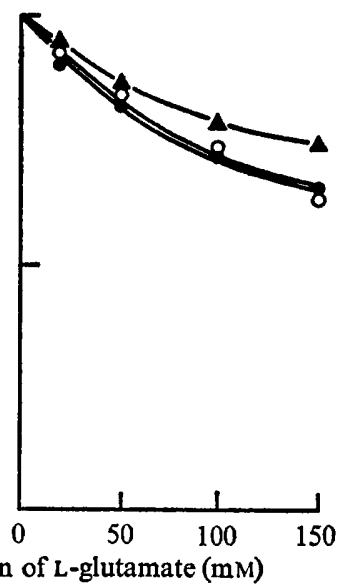

Fig. 3. Influence of L-glutamate concentration on the activities of GOGAT and glutamate dehydrogenase extracted from different bacteria. (a) Glutamate dehydrogenase $(\Delta)$ and GOGAT ( $\left(\right.$ ) from Aerobacter aerogenes (glucose-limited and $\mathrm{NH}_{3}$-limited, respectively), and GOGAT from $\mathrm{NH}_{3}$-limited Erwinia carotovora $(\mathrm{O})$. (b) Glutamate dehydrogenase $(\boldsymbol{\Delta})$ and GOGAT (๑) from Bacillus subtilis var. niger (glucose-limited and $\mathrm{NH}_{3}$-limited, respectively), and GOGAT from $\mathrm{NH}_{3}$-limited $B$. subtilis $\mathrm{w} 23$ organisms $(\mathrm{O})$. 
the medium also caused suppression of GOGAT synthesis in $E$. carotovora and $A$. aerogenes, even though their intracellular free glutamate levels were only marginally different from those of $\mathrm{NH}_{3}$-limited organisms. Presumably, in these cases at least, it could not have been glutamate per se that was the repressor molecule.

As well as affecting the synthesis of glutamate dehydrogenase and GOGAT, glutamate also markedly influenced their activities (Figs. $3 a, b$ ). In this respect there were obvious differences between Gram-positive and Gram-negative bacteria; enzymes from the former were much less sensitive to end-product inhibition; this correlated with their having a much greater 'pool' content of free glutamate (Table I ; see also Tempest, Meers \& Brown, I970 b).

\section{DISCUSSION}

Glutamate occupies a central position in bacterial amino acid metabolism, acting as an amino donor in the synthesis of practically all other amino acids. Thus control of glutamate synthesis is fundamental to the control of amino acid synthesis generally and, thereby, to the control of protein synthesis and growth. Glutamate can be formed directly from 2-oxoglutarate and $\mathrm{NH}_{3}$ by glutamate dehydrogenase and, in most bacteria, no other route of synthesis from $\mathrm{NH}_{3}$ was known until the finding by Tempest et al. (1970a) that $\mathrm{NH}_{3}$-limited Aerobacter aerogenes could effect synthesis by a twostep process involving a novel enzyme, 'glutamine (amide):2-oxo-glutarate aminotransferase oxido-reductase (NADP)'. It is now evident that this enzyme is not peculiar to $\mathrm{NH}_{3}$-limited $A$. aerogenes, nor, indeed, to $\mathrm{NH}_{3}$-limited bacteria. Although GOGAT was present in all of the $\mathrm{NH}_{3}$-limited bacteria which we examined, some (particularly Erwinia carotovora, which seemingly totally lacks a glutamate dehydrogenase) synthesized it 'constitutively'. It is reasonable to conclude, therefore, that in bacteria the potential to synthesize glutamate from $\mathrm{NH}_{3}$ and 2-oxoglutarate, via reactions catalysed by glutamine synthetase and GOGAT, is not uncommon; indeed, it may be a regular pathway of $\mathrm{NH}_{3}$ assimilation in most, if not all, bacteria that are able to grow in media in which $\mathrm{NH}_{3}$ provides the sole source of utilizable nitrogen.

No simple model for the co-ordinated control of glutamate dehydrogenase and GOGAT syntheses can be suggested. Addition of L-glutamate ( $50 \mathrm{~mm}$ ) to phosphatelimited cultures of Aerobacter aerogenes and Erwinia carotovora suppressed the synthesis of both enzymes but clearly glutamate per se was not the repressor. Thus, when glutamate was provided as the sole $\mathrm{N}$-source to an $\mathrm{N}$-limited culture of $A$. aerogenes, the 'pool' free glutamate level was only slightly changed (Table I) yet the synthesis of GOGAT was still totally repressed. Again, when $\mathrm{NaCl}(2 \%, \mathrm{w} / \mathrm{v})$ was added to the $\mathrm{NH}_{3}$-limited $A$. aerogenes culture, the 'pool' glutamate level was greatly increased but the cellular contents of GOGAT and glutamate dehydrogenase were only partially affected (Table I).

Large differences were apparent both in the amount of GOGAT present in various $\mathrm{NH}_{3}$-limited bacteria (Table I) and in their $K_{m}$ values for glutamine and 2-oxoglutarate (Table 2), but again no common patterns are evident among the organisms examined. For example, although, on average, the Gram-positive bacteria contained the greater amounts of GOGAT and had the lower $K_{m}$ values for glutamine and 2-oxoglutarate, there were notable exceptions; for example, the enzyme from the Gram-positive organism, Bacillus subtilis var. niger, had a high $K_{m}$ for glutamine whilst that from Gram-negative Pseudomonas fluorescens had a low $K_{m}$ for the same substrate. On the 
other hand, however, in every case the GOGAT activity was markedly affected by $\mathrm{pH}$ and had a common optimal activity in the range $\mathrm{pH} 7 \cdot 6$ to $8 \cdot 0$, and invariably GOGAT from the Gram-negative organisms was more sensitive to glutamate inhibition than the enzyme from the Gram-positive species.

The synthesis of glutamate from $\mathrm{NH}_{3}$ and 2-oxoglutarate, via glutamine and GOGAT, requires the participation of an active glutamine synthetase. Significantly, bacterial glutamine synthetases generally are found in considerable amounts in organisms whose growth has been limited by $\mathrm{NH}_{3}$ deprivation (Woolfolk, Shapiro \& Stadtman, 1966; Wu \& Yuan, I968; Pateman, I969). Glutamine synthetases characteristically have a low $K_{m}$ for ammonia, and this fact led Umbarger (I969) to suggest that they may act as 'scavengers' for $\mathrm{NH}_{3}$ (which would provide a functional basis for their derepressed synthesis in $\mathrm{NH}_{3}$-limited environments). The results reported in this paper support and extend Umbarger's hypothesis in that they show that glutamine synthetase (in conjunction with GOGAT) facilitates the synthesis of glutamate from $\mathrm{NH}_{3}$ under conditions where glutamate dehydrogenase (by virtue of its high $K_{m}$ for $\mathrm{NH}_{3}$ ) would be functionally inadequate. In this connexion, it was apparent (Table I) that, with all the organisms examined, $\mathrm{NH}_{3}$-limitation effected an enormous decrease in their glutamate dehydrogenase contents. Ammonia-limited bacteria contained exceedingly little free ammonia (Tempest et al. I970 b) so that, even if present, glutamate dehydrogenase would be grossly subsaturated; but how $\mathrm{NH}_{3}$-limitation could effect cessation of glutamate dehydrogenase synthesis is not obvious.

We are most grateful to Mr J. R. H. Slade for carrying out the amino acid analyses, and to Mr T. H. Dunham for his skilled technical assistance.

\section{REFERENCES}

Dixon, M. \& WebB, E. C. (1964). Enzymes, 2nd edn. London: Longmans Green.

Evans, C. G. T., Herbert, D. \& Tempest, D. W. (1970). The continuous cultivation of microorganisms. II. Construction of a chemostat. In Methods in Microbiology, vol. 2, pp. 277-328. London and New York: Academic Press.

Herbert, D., Phipps, P. J. \& Tempest, D. W. (1965). The chemostat: design and construction. Laboratory Practice 14, I I 50-I 16I.

HugHES, D. E. (195I). A press for disrupting bacteria and other micro-organisms. British Journal of Experimental Pathology 32, 97-109.

MeERS, J. L., Tempest, D. W. \& Brown, C. M. (I970). A novel pathway of glutamic acid synthesis in Aerobacter aerogenes. Journal of General Microbiology 6o, x.

PATEMAN, J. A. (1969). Regulation of synthesis of glutamate dehydrogenase and glutamine synthetase in micro-organisms. Biochemical Journal $11_{5}, 769-775$.

STICKLAND, L. H. (I95I). The determination of small quantities of bacteria by means of the biuret reaction. Journal of General Microbiology 5, 698-703.

Tempest, D. W., Meers, J. L. \& Brown, C. M. (I970a). Synthesis of glutamate in Aerobacter aerogenes by a hitherto unknown route. Biochemical Journal II7, 405-407.

Tempest, D. W., MeERs, J. L. \& Brown, C. M. (1970 $b$ ). Influence of environment on the content and composition of bacterial free amino acid pools. Journal of General Microbiology 64, 17I-I 85 .

UMBARger, H. E. (1969). Regulation of amino acid metabolism. Annual Review of Biochemistry $\mathbf{3}^{8}$, 323-370.

Woolfolk, C. A., Shapiro, B. \& Stadtman, E. R. (I966). Regulation of glutamine synthetase. I. Purification and properties of glutamine synthetase from Escherichia coli. Archives of Biochemistry and Biophysics II6, I77-192.

Wu, C. \& YUAN, L. H. (1968). Regulation of synthesis of glutamine synthetase in Escherichia coli. Journal of General Microbiology 51, 57-66. 